\title{
Clinical characterization of a novel calcium sensing receptor genetic alteration in a Greek patient with autosomal dominant hypocalcemia type 1
}

\author{
Anna Papadopoulou, ${ }^{1}$ Evangelia Gole, ${ }^{1}$ Katerina Melachroinou, ${ }^{2}$ \\ Theoni Trangas, ${ }^{3}$ Evaggelia Bountouvi, ${ }^{1}$ Anastasios Papadimitriou ${ }^{1}$
}

${ }^{1}$ Third Department of Pediatrics, National and Kapodistrian University of Athens, University General Hospital "Attikon", Athens, Athens, Greece; 'Division of Basic Neurosciences, Biomedical Research Foundation of the Academy of Athens, Athens, Greece; ${ }^{3}$ Department of Biological Applications and Technology, University of loannina, loannina, Greece

\begin{abstract}
OBJECTIVE: Autosomal dominant hypocalcemia (ADH) is a rare familial or sporadic syndrome associated with activating mutations in the calcium sensing receptor $(C a S R)$ gene. The aim of this study was to assess the functional significance of a novel CaSR mutation and, moreover, to present the clinical characteristics and the bone mineral density (BMD) progression from early childhood to late puberty in a patient with ADH. DESIGN: Genetic analysis of the CaSR gene was performed in a patient who presented in the neonatal period with hypocalcemic seizures and biochemical features of ADH. The functional impact of the novel mutation identified was assessed in cultured HEK $293 \mathrm{~T}$ cells, transfected with either the wild type (WT) or mutant CaSR, by evaluating intracellular calcium $\left(\left[\mathrm{Ca}^{2+}\right]_{i}\right)$ influx after stimulation with extracellular calcium $\left(\mathrm{Ca}^{2+}\right)$. Several BMD measurements were performed during the patient's follow-up until late puberty. RESULTS: A novel CaSR mutation (p.L123S) was identified, which, as demonstrated by functional analysis, renders CaSR more sensitive to extracellular changes of $\mathrm{Ca}^{2+}$ compared with the WT, although the difference is not statistically significant. BMD measurements, from early childhood to late puberty, revealed high normal to elevated BMD. CONCLUSION: We present the first Greek patient, to our knowledge, with sporadic ADH due to a novel gain-of-function mutation of the $C a S R$ gene.
\end{abstract}

Key words: Autosomal dominant hypocalcemia, Bone mineral density, Calcium sensing receptor, Hypoparathyroidism

Address for correspondence:

Anna Papadopoulou, Third Department of Pediatrics, Athens

University Medical School, University General Hospital

"Attikon", Athens, Greece; 1 Rimini Str., 12462 Athens, Greece;

Tel.: +30 2105832228; Fax: +30 2105832229;

E-mail: anpapado@med.uoa.gr

Received: 08-03-2017, Accepted: 03-04-2017

\section{INTRODUCTION}

Hypocalcemia that is related to defects of the calcium sensing receptor (CaSR) and results from low parathyroid hormone (PTH) secretion is termed autosomal dominant hypocalcemia (ADH). Two types of $\mathrm{ADH}$ have been identified so far: $\mathrm{ADH}$ type 1 
(ADH1) and type 2(ADH2). The more common type is ADH1, which is the result of gain-of-function mutations of $\mathrm{CaSR} .{ }^{1} \mathrm{CaSR}$, a $\mathrm{G}$ protein-coupled cell surface receptor that serves as a "calciostat", is expressed in several cell types including parathyroid chief cells, calcitonin-producing thyroid $\mathrm{C}$ cells, bone cells and renal tubular cells. The recently recognized ADH2 is caused by germline gain-of-function mutations of GNA11 which encodes the a-subunit of G11 $\left(\mathrm{Ga}_{11}\right)$, a G-protein that transduces CaSR signaling in the parathyroid glands. $^{2}$

$\mathrm{ADH} 1$ is a rare familial or sporadic syndrome with clinical presentation that varies from mild asymptomatic to severe hypocalcemia and which may present in neonatal life with seizures or later with hypocalcemic symptoms such as paresthesia, carpopedal spasm or afebrile seizures. ${ }^{3}$ Activating CaSR mutations increase the sensitivity of the receptor to extracellular calcium $\left(\mathrm{Ca}^{2+}\right)$, resulting in low or inappropriately normal PTH levels and reduced renal $\mathrm{Ca}^{2+}$ reabsorption. Subsequently, affected patients develop hypocalcemia, hyperphosphatemia, hypomagnesemia and absolute or relative hypercalciuria. Patients with $\mathrm{ADH}$ may also present with complications due to hypercalciuria, like renal stones, nephrocalcinosis, renal impairment and basal ganglia calcifcations. ${ }^{4}$ Regarding the bone metabolism of patients with ADH1, the possible impact of gain-of-function CaSR mutations on bone mineral density (BMD) has not been clarified.

Here we present the first patient, to our knowledge, of Greek origin with ADH1 who carries a novel mutation of the CaSR gene. We report the functional analysis of the mutation and the progression of bone mineral density from childhood through puberty.

\section{MATERIALS AND METHODS}

\section{Case report}

Our patient was a 17-day old Greek male who presented to our pediatric department with seizures. He was born at term, following an uneventful pregnancy, with normal weight, length and head circumference. He was the product of healthy unrelated parents. At presentation, biochemical investigation showed severe hypocalcemia with normal phosphate, magnesium and $1,25(\mathrm{OH})_{2} \mathrm{D}_{3}$, while $\mathrm{PTH}$ was at the lowest level (Table 1). With the working diagnosis of hypoparathyroidism, calcitriol and Ca supplementation were administered; however, the hypocalcemia was difficult to correct. During the first year of life, serum Ca levels ranged from 6.8-9.1 mg/dl and spot urinary $\mathrm{Ca}^{++} / \mathrm{Cr}$ from $0.3-0.6 \mathrm{mg} / \mathrm{mg}$ (normal values between 7-18 months $<0.6) .{ }^{5}$ A renal ultrasound scan, performed at the age of 10 months, showed grade 1 nephrocalcinosis. The relatively high urine $\mathrm{Ca}$ concentration despite low serum Ca suggested that the patient had ADH. Hence, we aimed to keep serum Ca levels at around $7 \mathrm{mg} / \mathrm{dl}$ and urinary $\mathrm{Ca}$ within the normal range. To achieve this, the patient was also administered hydrochlorothiazide. On this treatment, serum Ca ranged from $6.8-7.6 \mathrm{mg} / \mathrm{dl}, 24 \mathrm{~h}$-urinary $\mathrm{Ca}^{++}$ from $2.8-6 \mathrm{mg} / \mathrm{kg} / 24 \mathrm{~h}(<4)$ and the serum calcium $\mathrm{x}$ phosphate product was $<55$. Currently, our patient is 16 years old, with normal growth (height: 170 $\mathrm{cm}, 25^{\text {th }}-50^{\text {th }}$ percentile, and weight: $79.5 \mathrm{~kg}, 75^{\text {th }}$ $90^{\text {th }}$ percentile) and Tanner 5 pubertal development. He is still on calcitriol and hydrochlorothiazide; he has normal biochemistry, except for hypocalcemia, as well as normal renal function and stable grade 1 nephrocalcinosis. BMD determined at the age of $5,7.5,12$ and 15.5 years was always increased or high-normal (z-score: $+2.1,+1.45,+2.1$ and +1.6 , respectively). The measurements were performed in the lumbar spine (L1-L4) by dual-energy X-ray absorptiometry (DXA) with a Hologic QDR-1000 upgraded unit.

\section{DNA studies}

Genomic DNA was isolated from whole blood and exons 2-7 of the CaSR gene (NM_000388) and their respective flanking regions were PCR amplified and sequenced. Informed consent was obtained from the parents of the patient. The analysis of the CaSR gene revealed the novel heterozygous muta-

Table 1. Laboratory findings of patient's initial presentation at the age of 17 days old

\begin{tabular}{lc}
\hline Calcium $(\mathrm{mg} / \mathrm{dl})$ & $6.3[8.8-10.8]$ \\
Phosphate $(\mathrm{mg} / \mathrm{dl})$ & $5.9[3.8-6.5]$ \\
Magnesium $(\mathrm{mg} / \mathrm{dl})$ & $1.8[1.6-2.6]$ \\
PTH $(\mathrm{pg} / \mathrm{ml})$ & $8[9-52]$ \\
$1,25(\mathrm{OH})_{2} \mathrm{D}_{3}(\mathrm{pg} / \mathrm{ml})$ & $31[8-62]$ \\
\hline
\end{tabular}


tion c.368T $>$ C in exon 3 resulting in the substitution of the amino acid leucine by the amino acid serine (p.L123S). This mutation was not detected at position 123 of the CaSR protein in any of the parents, nor in 50 unrelated individuals of the general population.

\section{Functional studies}

Human CaSR cDNA cloned in the pCR 3.1 plasmid (pCR3.1/hCaSR) (Invitrogen) was kindly provided by Dr Lia Baldini, University of Limoges, France. The $368 \mathrm{~T}>\mathrm{C}$ change was directly introduced to the wild type CaSR plasmid to generate the mutated receptor using the Quick Change Site-directed Mutagenesis kit (Stratagene, La Jolla, CA, USA) according to the manufacturer's instructions. HEK 293T cells were transiently transfected with CaSR cDNA $(12 \mu \mathrm{g})$ in $10 \mathrm{~cm}$ tissue culture plates, using calcium phosphate DNA precipitates. $\mathrm{Ca}^{2+}$ measurements were performed $60 \mathrm{~h}$ post transfection where cells were loaded with Fura 2-AM, as already described ${ }^{6}$ Cell aliquots $\left(1.5 \times 10^{6}\right)$ were transferred to a thermostated cuvette $\left(37^{\circ} \mathrm{C}\right)$, maintained under continuous stirring and analyzed in a Perkin-Elmer LS-55. The basal levels of $\left[\mathrm{Ca}^{2+}\right]_{i}$ were measured upon addition of $1 \mathrm{mM}$ EGTA and presented as $\mathrm{nM}$. To investigate alterations in CaSR function, $\mathrm{CaCl}_{2}(3 \mathrm{mM})$ was reintroduced into the medium and $\left[\mathrm{Ca}^{2+}\right]_{\mathrm{i}}$ increase was recorded. The induction of $\left[\mathrm{Ca}^{2+}\right]_{i}$ influx was estimated as the net $\mathrm{nM}$ difference between the peak of $\left[\mathrm{Ca}^{2+}\right]_{\mathrm{i}}$, upon extracellular $\mathrm{CaCl}_{2}$ addition and the baseline. All data are expressed as mean \pm SEM. Statistical analysis for multiple comparisons was performed using a one-way analysis of variance (ANOVA), followed by Tukey HSD post-hoc test. Non-directional Student's t-tests were performed for comparisons involving only two groups. All statistical analyses were conducted using GraphPad Prism software. Results were considered statistically significant at $\mathrm{p} \leq 0.05$.

\section{RESULTS}

As shown in Figure 1A, WT over-expressing cells present a threshold of $\left[\mathrm{Ca}^{2+}\right]_{i}$ of $118.6 \pm 5.6 \mathrm{nM}$. The cells harboring the $368 \mathrm{~T}>\mathrm{C}$ genetic change exhibit a trend for increased $\left[\mathrm{Ca}^{2+}\right]_{\mathrm{i}}(129.1 \pm 11.3 \mathrm{nM})$, which however is not significant. Similarly, stimulation with exogenous addition of $3 \mathrm{mM} \mathrm{CaCl}_{2}$ (Figure 1B) resulted in a relatively increased $\mathrm{Ca}^{2+}$ mobilization
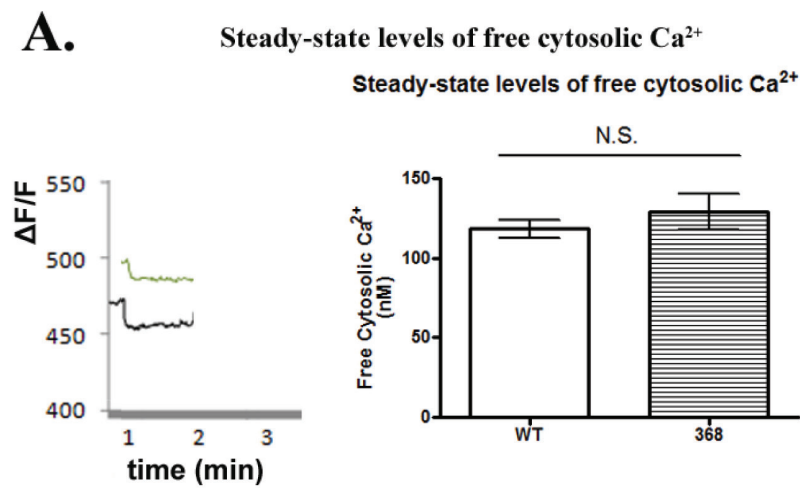

B.
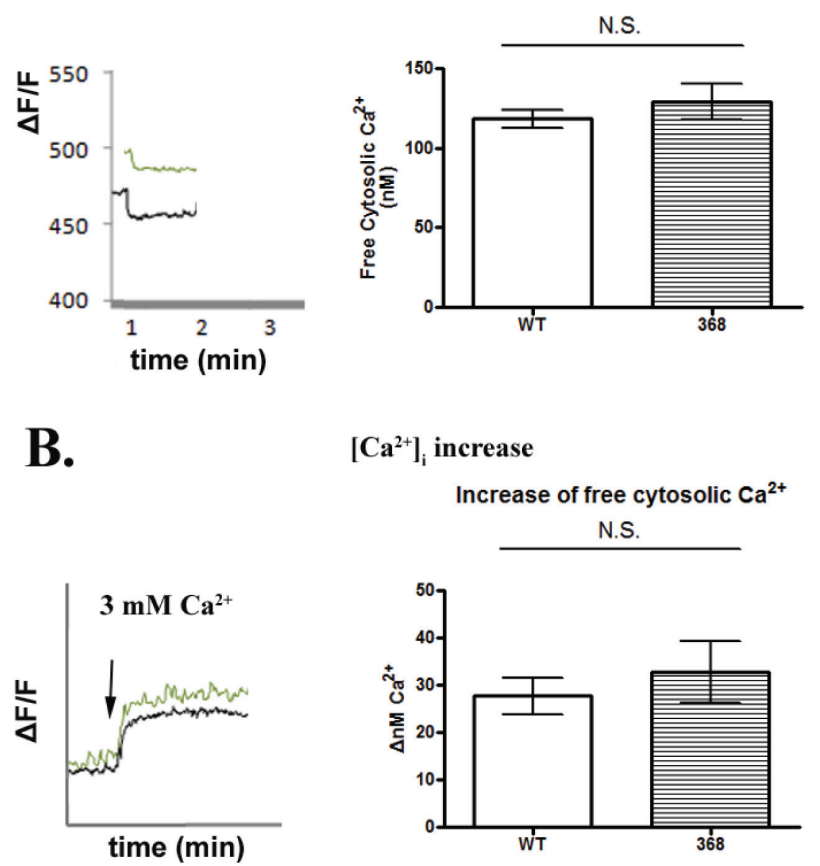

Figure 1. Alterations of $\mathrm{Ca}^{2+}$-evoked responses in the presence of CaSR mutation. HEK 293T cells transfected with wild-type (WT) or mutant CASRs (368) were loaded with Fura 2-AM, and $\mathrm{Ca}^{2+}$ measurements were performed using a fluorimeter. (A) Steady-state levels of free cytosolic $\mathrm{Ca}^{2+}$. Representative $\mathrm{Ca}^{2+}$ traces are shown in the left panel and quantitative analysis of the $\left[\mathrm{Ca}^{2+}\right]_{\mathrm{i}}$ is depicted in the right panel. $\mathrm{n}=3$; N.S.=not significant, comparing between WT and 368 mutation, using unpaired t-test. (B) $\mathrm{Ca}^{2+}$ influx upon stimulation with $\mathrm{CaCl} 2$. Representative $\mathrm{Ca}^{2+}$ measurements are shown in the left panel and quantitative estimation of $\left[\mathrm{Ca}^{2+}\right]_{\mathrm{i}}$ increase $(\Delta \mathrm{nM})$ upon $\mathrm{CaCl} 2$ stimulation is depicted in the right panel. $n=3$; N.S.=not significant, comparing between WT and 368 mutation, using unpaired t-test.

in the $368 \mathrm{~T}>\mathrm{C}$ over-expressing cells $(32.80 \pm 6.47$ $\Delta \mathrm{nM})$ in comparison to WT $(27.77 \pm 3.87 \Delta \mathrm{nM})$, which was not statistically significant.

\section{DISCUSSION}

In this study we report a novel heterozygous variant of unknown clinical significance in exon 3 of the CaSR gene in a patient with severe hypocalcemia and hypercalciuria. The alteration identified (p.L123S) was not reported in the Human Gene Mutation Database nor in reference databases (i.e. 1000 Genomes), while the functional analysis demonstrated that the altered 
CaSR was more sensitive to extracellular changes of $\mathrm{Ca}^{2+}$ compared with the wild type, although the difference was not significant. Furthermore, according to the prediction tools PolyPhen and SIFT, this mutation is characterized as probably damaging (score: 0.990 ) or tolerated (score: 0.460), respectively.

The p.L123S genetic change is localized in the extracellular domain of the receptor which is essential for ligand binding. It has been suggested that mutations in this region affect the three-dimensional structure of the receptor, resulting in a "more sensitive" conformational state. ${ }^{7}$ This finding is also supported by a previous mutagenesis study showing that mutations localized between amino acids 116 and 136 in the CaSR protein lead to increased basal activity of the receptor as well as increased affinity for $\mathrm{Ca}^{2+}$. However, some mutations seem to result in mild asymptomatic hypocalcemia, despite the localization of the alterations in critical protein regions, while other mutations, located in the same protein region, have different effects on the receptor's activity. ${ }^{7}$ Our patient presented with severe hypocalcemia and seizures in the neonatal period that did not correlate with the degree of his CaSR sensitivity to changes of exogenous $\mathrm{Ca}^{2+}$ concentrations.

Interestingly, our proband also had mildly increased BMD despite chronic hypocalcemia. This could be attributed to chronic hypoparathyroidism, which is characterized by reduced bone remodeling and increased bone mass. ${ }^{9}$ Patients with ADH present PTH levels in the low normal or slightly below the normal range in contrast to patients with hypoparathyroidism, who have very low to undetectable PTH levels. Due to the rarity of this disorder in childhood, studies on the bone mineral density of children with hypoparathyroidism are scarce. In a NIH cohort of more than 30 hypoparathyroid children, bone mineral density was not increased. ${ }^{10}$

Although little is known about the effects of CaSR mutations on bone metabolism, it has been shown that CaSR is expressed in bone cells, while in vitro studies have identified anabolic effects of overactive CaSR in bone by its promotion of osteoblast differentiation and inhibition of osteoclastogenesis. However, the data from in vivo studies, which are controversial, suggest that CaSR activation leads to enhanced bone resorption and mild osteopenia, although similar implications in humans have not been demonstrated as yet. ${ }^{11}$

From the very few studies examining the BMD of patients with $\mathrm{ADH}$, it seems that patients with different activating CaSR mutations may present with low, normal or high BMD. ${ }^{12-15}$ It is interesting to note that our patient, as well as the three patients with increased BMD previously reported, ${ }^{12}$ all harbored mutations within the same region of the extracellular domain of the receptor. The possible correlation between BMD and specific mutations, especially if also including bone histomorphometry data, would add further knowledge regarding the effects of activating CaSR mutations on human bone density and metabolism.

In conclusion, we present, to the best of our knowledge, the first patient of Greek origin who carries a novel genetic alteration of the CaSR gene while presenting with severe neonatal hypocalcemia. More studies on the effect of CaSR mutations on BMD are needed.

\section{ACKNOWLEDGEMENTS}

We thank Dr Lia Baldini, University of Limoges, France, for providing the CaSR plasmid and Prof A. Lienhardt and Dr C. Magdelaine for the sequencing analysis of the CaSR gene.

\section{DECLARATION OF INTEREST}

The authors declare that they have no conflict of interest.

\section{REFERENCES:}

1. Pearce SH, Williamson C, Kifor O, et al, 1995 A familial syndrome of hypocalcemia with hypercalciuria due to mutations in the calcium-sensing receptor. $\mathrm{N}$ Engl $\mathrm{J}$ Med 335: 1115-1122.

2. Nesbit MA, Hannan FM, Howles SA, et al, 2013 Mutations affecting G-protein subunit $\alpha 11$ in hypercalcemia and hypocalcemia. N Engl J Med 368: 2476-2486.

3. Raue F, Pichl J, Dörr HG, et al, 2011 Activating mutations in the calcium-sensing receptor: genetic and clinical spectrum in 25 patients with autosomal dominant hypocalcaemia - A German survey. Clin Endocrinol (Oxf) 75: 760-765.

4. Hendy GN, Guarnieri V, Canaff L, 2009 Calcium- 
sensing receptor and associated diseases. Prog Mol Biol Transl Sci 89: 31-95.

5. Sargent JD, Stukel TA, Kresel J, Klein RZ, 1993 Normal values for random urinary calcium to creatinine ratios in infancy. J Pediatr 123: 393-397.

6. Papazafiri P, Bossi M, Meldolesi J, 1994 Expression of muscle calsequestrin in epithelial HeLa cells: distribution and functional role. Biochim Biophys Acta 1223: 333-340.

7. Hu J, Spiegel AM, 2007 Structure and function of the human calcium-sensing receptor: insights from natural and engineered mutations and allosteric modulators. J Cell Mol Med 11: 908-922.

8. Jensen AA, Spalding TA, Burstein ES, et al, 2000 Functional importance of the Ala(116)-Pro(136) region in the calcium-sensing receptor. Constitutive activity and inverse agonism in a family C G-protein-coupled receptor. J Biol Chem 275: 29547-29555.

9. Clarke BL, 2014 Bone disease in hypoparathyroidism. Arq Bras Endocrinol Metabol 58: 545-552.

10. Ficcadenti A, Zallocco F, Neri R, Giovannini L, Tirabassi G, Balercia G, 2015 Bone density assessment in a cohort of pediatric patients affected by 22q11DS. J Endocrinol Invest 38: 1093-1098.

11. Cianferotti L, Gomes AR, Fabbri S, Tanini A, Brandi ML, 2015 The calcium-sensing receptor in bone metabolism: from bench to bedside and back. Osteoporos Int 26: 2055-2071.

12. Pearce SH, Bai M, Quinn SJ, Kifor O, Brown EM, Thakker RV, 1996 Functional characterization of calcium-sensing receptor mutations expressed in human embryonic kidney cells. J Clin Invest 98: 1860-1866.

13. Theman TA, Collins MT, Dempster DW, et al, 2009 PTH(1-34) replacement therapy in a child with hypoparathyroidism caused by a sporadic calcium receptor mutation. J Bone Miner Res 24: 964-973.

14. Kim MY, Tan AH, Ki CS, et al, 2010 Autosomal dominant hypocalcemia caused by an activating mutation of the calcium-sensing receptor gene: the first case report in Korea. J Korean Med Sci 25: 317-320.

15. Sørheim JI, Husebye ES, Nedrebø BG, et al, 2010 Phenotypic variation in a large family with autosomal dominant hypocalcaemia. Horm Res Paediatr 74: 399405 . 